\title{
Anatomopathological and immunohistochemical findings of natural Brucella abortus infection in buffalo uterin and peri-vaginal lymph nodes
}

\author{
Achados anatomopatológicos e imunohistoquímicos da infecção natural por Brucella abortus no \\ útero e linfonodos perivaginais de búfalas
}

Hallazgos anatomopatológicos e inmunohistoquímicos de la infección natural por Brucella abortus en útero y ganglios linfáticos peri-vaginales de búfalas

\begin{abstract}
The present work aimed to evaluate the macro and microscopic lesions and the distribution of Brucella sp. in the reproductive tract of seropositive female buffaloes to brucellosis. Nineteen genital tracts and eighteen peri-vaginal lymph nodes from previous serum reagent animals to brucella were collected from slaughterhouse, processed and submitted to Fisher's exact test (5\%). It was not observed uterine macroscopic lesions from non-pregnant and pregnant until the four month, as well as are infrequent in the peri-vaginal lymph nodes. Microscopical lesions were found as lymphocyte clustering in caruncle in the placentome, necrosis and desquamation of chorionic cells, and in the perivaginal lymph nodes may occur oedema, increased neutrophil frequency, lymphocyte depletion, lymphoid hyperplasia, congestion, haemorrhage, and vasculitis. Thus, the IHC displayed great sensitivity to identify the presence of the bacterial antigen in tissues of seropositive animals of this species.
\end{abstract}

Keywords: Bacterium; Diagnostics; Infection diseases; Impact on reproduction; Zoonosis.

\section{Resumo}

O presente trabalho teve como objetivos avaliar as lesões macro e microscópicas e a distribuição de Brucella sp. no trato reprodutivo de búfalas soropositivas para a brucelose. Dezenove tratos genitais e dezoito linfonodos perivaginais de animais reagentes na sorologia à brucela foram coletados em matadouro, sendo realizada a análise macroscópica e histopatológica para a presença de lesões e imunohistoquímica para brucela com os dados - submetidos ao teste exato 
de Fisher (5\%). Não foram observadas lesões macroscópicas nos úteros gravídico até os quatro meses e nos não gravídicos, bem como são infrequentes nos linfonodos perivaginais. Lesões microscópicas foram encontradas contendo aglomerados de linfócitos na carúncula no placentomo, necrose e descamação das células coriônicas, e nos linfonodos perivaginais pode ocorrer edema, aumento da frequência de neutrófilos, depleção de linfócitos, hiperplasia linfóide, congestão, hemorragia e vasculite. Assim, o IHC apresentou grande sensibilidade para identificar a presença do antígeno bacteriano em tecidos de animais soropositivos desta espécie.

Palavras-chave: Bactéria; Diagnóstico; Doenças infecciosas; Impacto na reprodução; Zoonose.

\section{Resumen}

El presente estudio tuvo como objetivo evaluar las lesiones macro y microscópicas y la distribución de Brucella sp. en el tracto reproductivo de búfalas seropositivos para brucelosis. Diecinueve tractos genitales y dieciocho ganglios linfáticos perivaginales de animales que reaccionaron a la serología de brucella fueron recolectados en un matadero, procesados y sometidos a la prueba exacta de Fisher (5\%). No hubo lesiones macroscópicas en el útero gestante hasta los cuatro meses de edad y en las no gestantes, así como son infrecuentes en los ganglios linfáticos perivaginales. Se encontraron lesiones microscópicas que contenían grupos de linfocitos en la carúncula en el placentoma, necrosis y descamación de las células coriónicas, y en los ganglios linfáticos perivaginales, edema, aumento de la frecuencia de neutrófilos, depleción de linfocitos, hiperplasia de linfocitos, congestionamiento, hemorrágia y vasculitis. Así, la IHC mostró una gran sensibilidad para identificar la presencia del antígeno bacteriano en tejidos de animales seropositivos de esta especie.

Palabras clave: Bacteria; Diagnóstico; Enfermedades infecciosas; Impacto en la reproducción; Zoonosis.

\section{Introduction}

Brucellosis is an ancient disease and of cosmopolitan occurrence where bacteria have developed mechanisms to manipulate cellular immunity and resist cellular immune responses, thereby achieving intracellular persistence. Despite estimates of more than 500,000 new human cases per year, it remains often under-diagnosed and neglected among diseases affecting livestock in many countries (Baldi \& Giambartolomei., 2013). Moreover, in this disease the affected animal usually does not show definite clinical signs, except abortion and sterility. With regard to latent infection, the disease may mimic many others, however, this can be differentiated by clinical presentation and histopathological findings (Jang et al., 2010).

In spite of the control of brucellosis a diagnostic strategy is usually the combination of exams used in series, based on the choice of an easy to perform, cheap and good sensitivity screening test followed by a confirmatory test to be performed on samples serum test results that are positive in the screening test. Indeed, confirmatory tests for the diagnosis of brucellosis should have high sensitivity and specificity, considering the existence of infected animals that remain serologically negative for a considerable period after infection (Corbel et al., 2006; Meirelles-Bartoli \& Mathias., 2009, Meirelles-Bartoli et al., 2020). Further, the laboratory diagnosis also includes indirect tests that can be applied to milk or blood, as well as direct tests such as classical bacteriological tests and polymerase chain reaction (PCR), constituting a fundamental tool for the knowledge of the prevalence of brucellosis and for the prevention and control of infection in herds. The indirect diagnostic or serological methods are the detection of antibodies and are the most used when working with flocks, since they are fast, easy to perform and low cost, besides showing good sensitivity and specificity (Le Flèche et al., 2006; Paulin \& Ferreira Neto, 2008; Sousa et al., 2015a).

The immunohistochemistry (IHC) is a versatile method for the localization of tissue or cell specific antigens based on antigen-antibody recognition (Sozmen et al., 2004). On the other hand, in the literature there are few studies related to the IHC for B. abortus in buffaloes and most of them refer to the presence of the bacteria in fetal tissues (Xavier et al., 2009; Orlando et al., 2014), but the actual distribution of bacterial antigens in the treatment reproductive status of buffaloes remains without due clarification. In this sense, the present work aimed to evaluate the presence of $B$. abortus antigens in the reproductive tract of seroposite buffaloes to brucellosis, demonstrating the lesions, frequency, intensity and distribution of immunostaining through the IHC technique. 


\section{Methodology}

The project that gave origin to these data was submitted to the Ethics Committee on the use of animals of the Federal Rural University of Amazonia with no opinion, justified by the research does not involve the manipulation of live animals but followed the guidelines of the National Council for Control of Animal Experimentation (CONCEA) of Brazil.

The research is carried out with the objective of bringing new knowledge to society as stated by Pereira et al. (2018). In the present study of a qualitative nature, anatomopathological and immunohistochemical findings research was carried out.

\section{Collected samples}

Were collected uterine tissue from nineteen genital tracts and eighteen peri vaginal lymph nodes from previous serum reagent animals to Brucella sp. from a slaughterhouse and from each case, samples were processed immediately after the slaughter as follow: $\mathrm{n}=1$ for 30 days; $\mathrm{n}=4$ for 60 days; $\mathrm{n}=6$ for 120 days of gestation approximately, and $\mathrm{n}=8$ non-pregnant. The negative control came from one pregnant female of 120 days non-reactive to complement fixation test (CFT) along slaughter. Were used two lymph nodes tested previously for brucella as positive control for IHC.

\section{Histopathological and Immunohistochemical analyses}

From each case, fragments of the uterus and lymph nodes were fixed in neutral formalin buffered at $10 \%$ for at least 48 hours and, then processed routinely for inclusion in Paraplast ${ }^{\circledR}$ and cut to 4-5 $\mu \mathrm{m}$ and stained with hematoxylin and eosin (HE) for the histopathological analysis.

For the immunohistochemical (IHC) study, sections of 4-5 $\mu \mathrm{m}$ thick on signal histological slides (ImmunoSlide, EasyPath ${ }^{\circledR}$ ) were dewaxed in xylol (three incubations for $10 \mathrm{~min}$ ) and rehydrated in ethanol decreasing concentrations (99.3\% to $70 \%)$. The slides were then treated with citric acid solution $(0.01 \mathrm{M}, \mathrm{pH} 6.0)$, heating in microwave at high power 3 times for 5 min each. At this point, inhibition of the endogenous peroxidase was made by treatment in $10 \% \mathrm{H}_{2} \mathrm{O}_{2} /$ methanol solution for 20 to $30 \mathrm{~min}$. The sections were preincubated with blocking solution for $10 \mathrm{~min}$ (BSA in PBS buffer). After, incubated overnight with mouse Brucella abortus monoclonal antibody, at a dilution of 1:100, used as recommended by the manufacturer (Fitzgerald Industries International, Acton, Massachusetts, EUA). Then, after several washes, the sections were preincubated with blocking solution for $10 \mathrm{~min}$ (BSA in PBS buffer). Then incubation with the solution containing biotinylated secondary antibodies (Kit DAKO corporation, Santa Clara, CA, USA) for $30 \mathrm{~min}$ at room temperature, followed by washing in PBS and incubated in Kit solutions containing the streptavidin-peroxidase complex for $15 \mathrm{~min}$. After completion, the slides were washed in PBS buffer and the reaction product was developed by treatment with diaminobenzidine (Sigma, St. Louis, Missouri, USA) in $100 \mathrm{mM}$ Trissaline buffer containing $0.01 \% \mathrm{H}_{2} \mathrm{O}_{2}$. Then, sections were washed in distilled water, counterstained with Harris Hematoxylin, and mounted in histological resin for analysis on light microscope. Moreover, a classification was adopted to determine the immunostaining degree, as follow when occurring in isolated cells (+), in some small groups (++)and in several groups (+++).

\section{Statistical analyses}

Furthermore, the data were processed in spreadsheets and submitted to the statistical program SAS (University edition), where the frequencies of immunolabeling for uterus and peri-vaginal lymph node were submitted to Fisher's exact test. The significant consideration was 0.05 . 


\section{Results}

\section{Macroscopical and histological analyses peri-vaginal lymph node and uterine}

Peri-vaginal lymph nodes were analysed macroscopically, mostly showed no alterations. However, in a case, the lymph nodes were intense red colour and larger in relation to the other cases. Histologically, six lymph nodes showed normality and twelve were diagnosed with alterations, being seven presented loosening medullary zone as well as separation between lymphocyte cells (positive oedema). In a lymph node some neutrophils were most frequent (Figure 1A, 1D) and in four cases were found decreasing of lymphocytes, especially in the medullary zone (Figure 1B, 1C).

Figure 1. Serologically positive buffalo peri-vaginal lymph nodes to Brucella. A. Reaction with neutrophil infiltrate in the medullary (arrow). HE. Bar $=50 \mu \mathrm{m}$. B. Medullary region with rarefaction of lymphoid cells. HE. Bar $=100 \mu \mathrm{m}$. C. Vasculitis with infiltrates of macrophages, lymphocytes and plasma cells (arrow). HE. Bar $=100 \mu \mathrm{m}$. D. Lymphoid hyperplasia, with denser and thickened cord marrow (1), in the sinuses of the medullary increase of macrophages (2). HE. Bar $=100 \mu \mathrm{m}$.

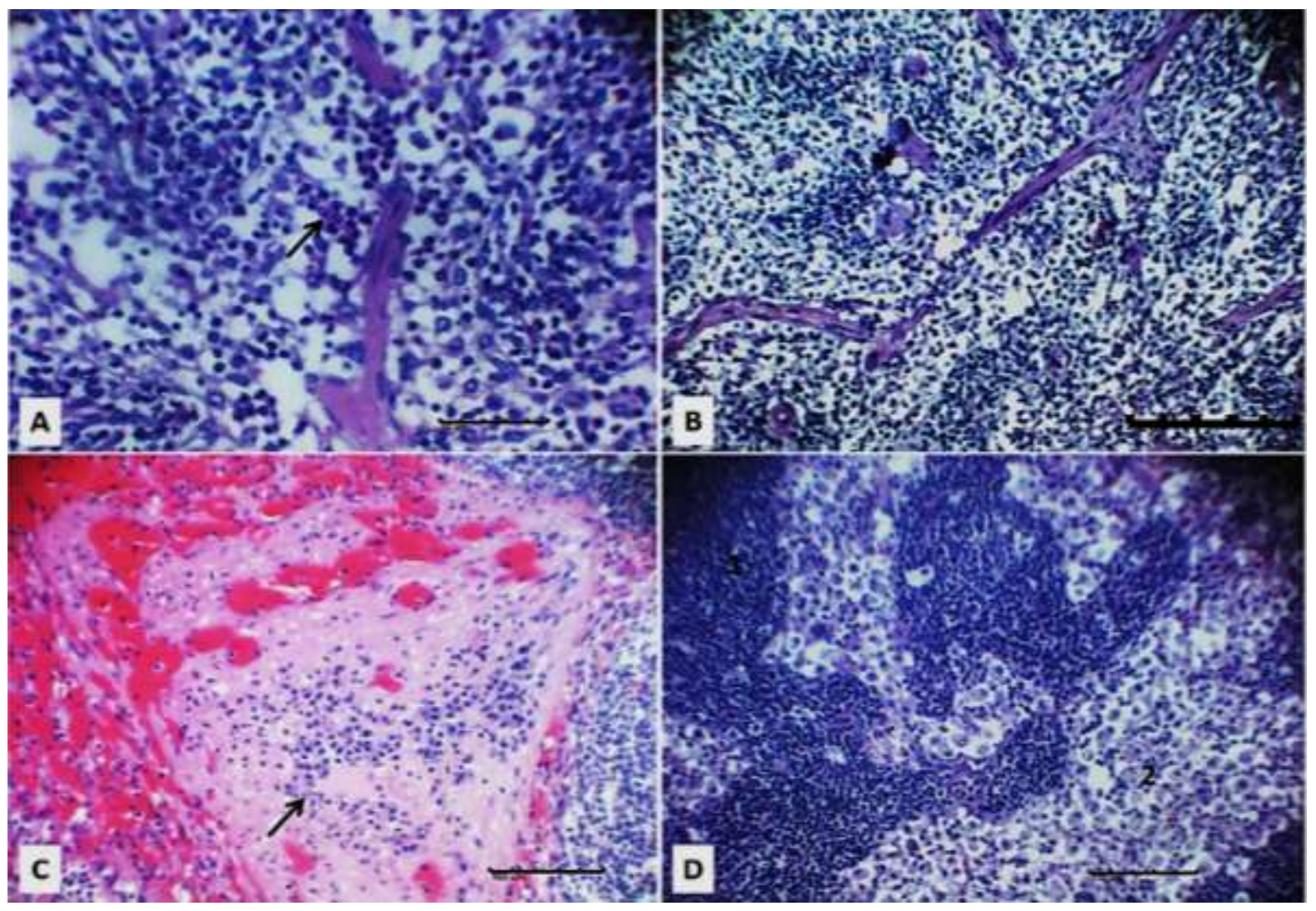

Source: Authors.

In this study, in gestational and non-gestational cases, macroscopic alterations of uterine infections were not observed. However, in uterine histological results were found three case from eight non-pregnant females, some small clusters of lymphocyte and plasmocyte cells with rare macrophages were observed in the compact layer of endometrium (Figure 2A), occurring also in the spongy endometrium and, no there was reaction in the basal endometrium. One of the cases had a prominent infiltrate of mononuclear cells and a small focus of calcification surrounded by macrophages also in the compact layer of endometrium.

In pregnant uterine tract (eleven cases), two cases presented caruncles in the placentome with several lymphocytic infiltrates and an apparent fibrosis. It was not possible to differ the chorionic villi from the placental villi, and one of them also 
had necrosis and chorionic cell desquamations (Figure 2B). In the non-pregnant females, four had small foci of mononuclear cells, predominating in the compact endometrium.

Figure 2. Photomicrographs of serologically positive buffalo uterine tissues to Brucella. A. Interstitial endometrial reaction with predominant infiltrate of lymphocytes and plasma cells. HE. Bar $=50 \mu \mathrm{m}$. B. Coagulative necrosis of chorionic villus (arrow) with associated haemorrhage. HE. Bar $=100 \mu \mathrm{m}$.

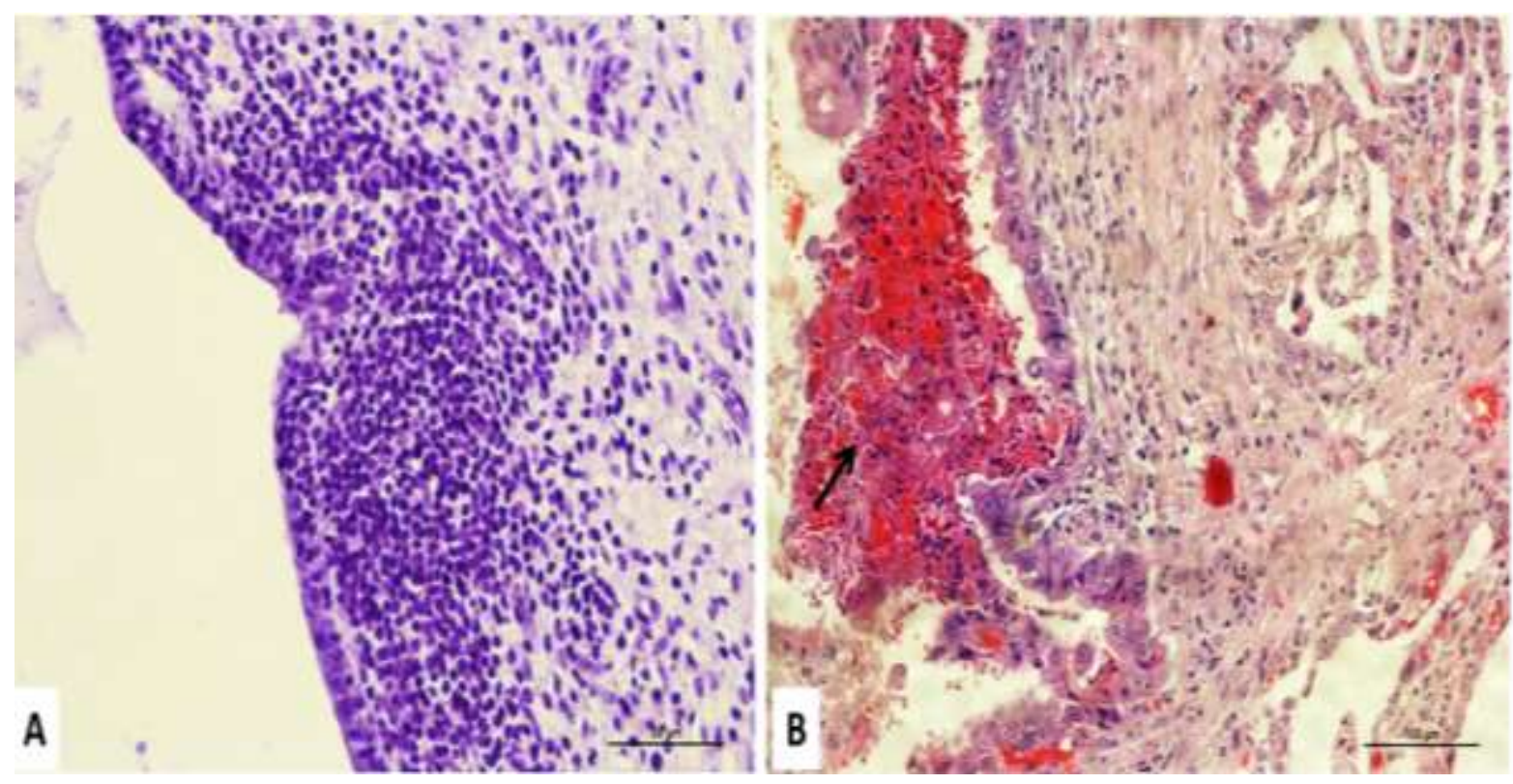

Source: Authors.

\section{Immunohistochemical analyses peri-vaginal lymph nodes and uterine}

The IHC analysis demonstrated immunostaining in golden brown for Brucella abortus antigen. Thus was observed significant difference among tissues studied $(\mathrm{p}<0.05)$, being $26.3 \%$ for uterine tissue $(5 / 19)$ and $83.33 \%$ for peri-vaginal lymph nodes $(15 / 18)$.

The immunolacalization of $B$. abortus antigen has been expressed on macrophages and predominantly on medular region of peri-vaginal lymph nodes. While the immunostaining intensity, in five cases the reations were (+) (Fig 3A), in nine $(++)$ and only a case (+++) (Fig 1B). 
Figure 3. Photomicrography of serologically positive buffalo peri-vaginal lymph nodes to Brucella. A. Anti-Brucella abortus immunostaining, staining the brown antigen on isolated macrophages (+) (arrows). B. Blushing cluster of macrophages (+++). Monoclonal primary antibody (LS-C194091) at 1:100 dilution with diaminobenzidine (DAB) and Harris haematoxylin staining settling. Bar $=50 \mu \mathrm{m}$.

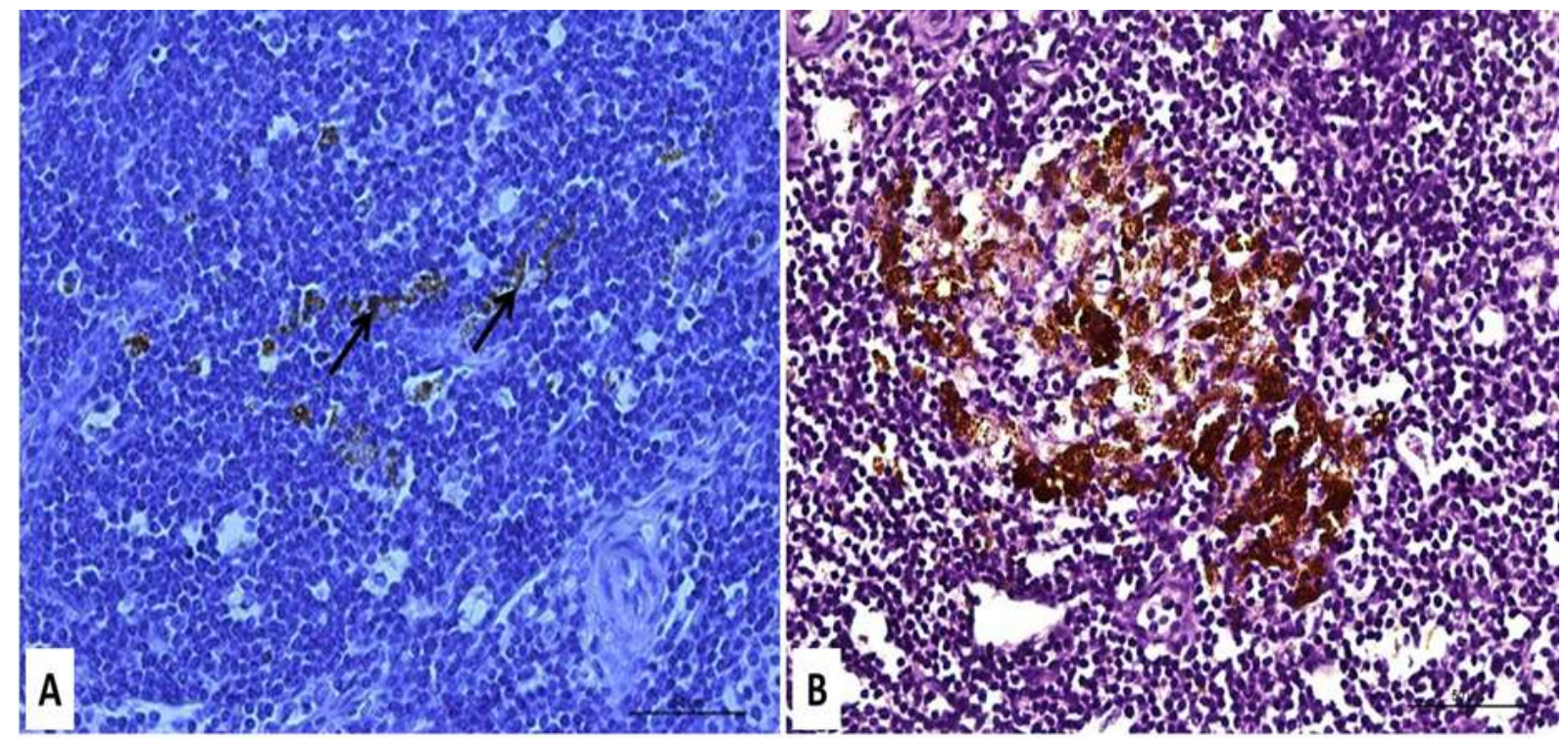

Source: Authors.

About location of B. abortus in the uterine tissue, immunostaining was observed at the level of the uterine epithelium of a pregnant female (Fig 4A). Similarly, a case occurred on four-month pregnant uterine tract, the immunostaining was less expressive in the cotyledons and more intense in the caruncle villi (Fig 4B). It also occurred in placental debris (Fig 4C) and some macrophages in the endometrium. The non-pregnant uterine tract was not observed immunostaining for the $B$. abortus antigen. 
Figure 4. Photomicrographs of serologically positive buffalo uterine tissue to Brucella. A. Immunostaining of anti-Brucella abortus by staining the brown antigen on cells of the uterine epithelium (arrows) (Case No. 41/14). B. Immunostaining on the surface of the chorionic villi (arrows) and less intensely on the caruncle (case 567/15). C. Immunostaining in areas of corion debris (arrows). Monoclonal primary antibody (LS-C194091) at 1: 100 dilution with diaminobenzidine (DAB) and Harris haematoxylin staining. Bar $=50 \mu \mathrm{m}$.

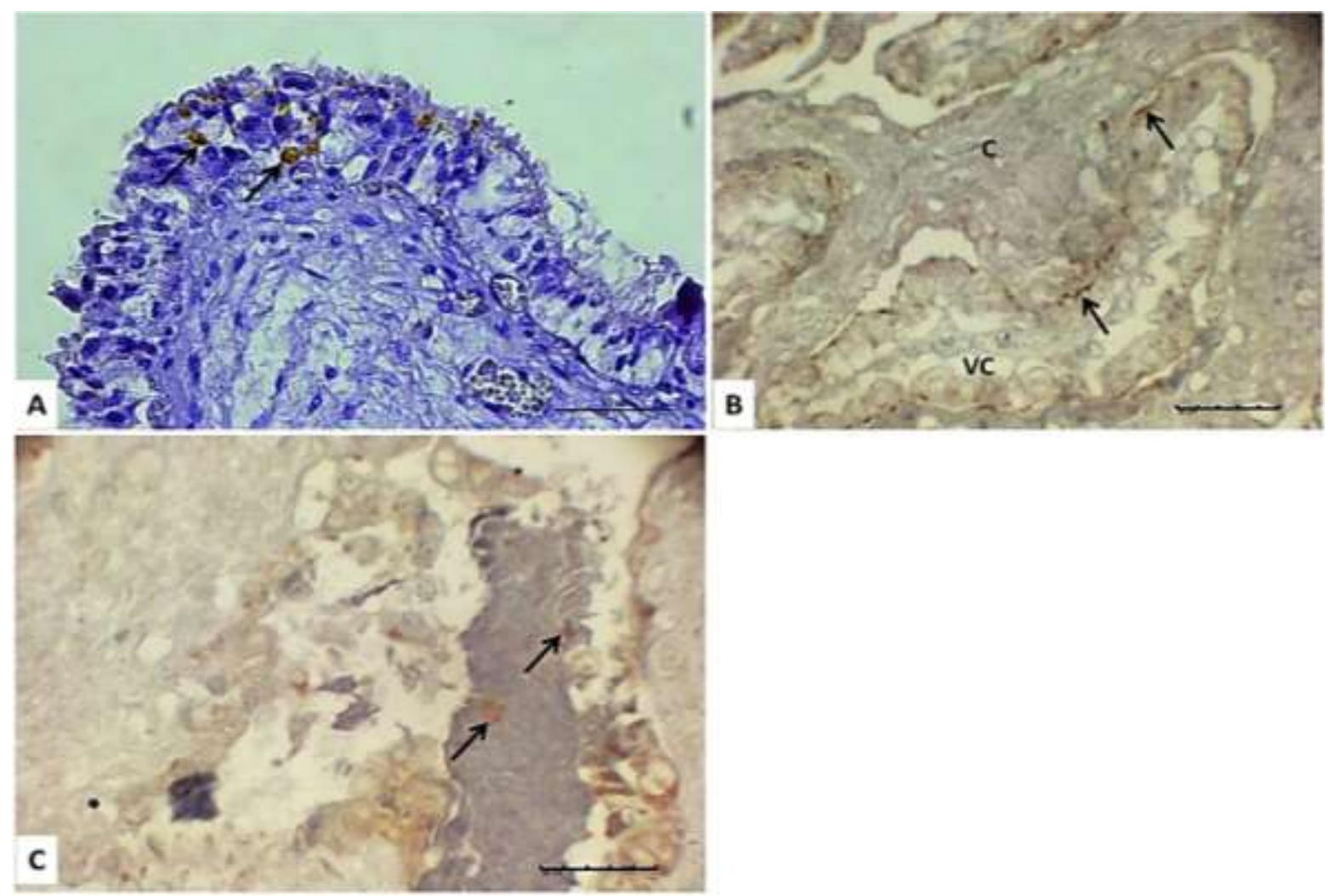

Source: Authors.

\section{Discussion}

Buffalo cows in advanced gestation (9th and 10th month) is possible to look placentome focal necrosis, fetid fibrinopurulent exudate, placental remnants, oedema, haemorrhage of chorioallantoic membrane, and other alterations (Sousa et al., 2015a), however, macroscopically such results were not observed in the present study that will evaluate uterine lesions in animals until the 4 th month of gestation.

In abortions caused by Brucella abortus in bovine cows (Pranav et al., 2013) observed the presence of endometrial fibrosis and calcification. However, these alterations were not observed in the present study, but mild non-specifc chronic endometritis was diagnosed through the absence of polymorphonuclear cells. (Ahmed et al., 2012) verified different forms of endometritis (ulcerative, granulomatous, hemorrhagic and chronic) in buffaloes infected naturally by $B$. melitensis, of which only the chronic one was observed in the present study.

Histological evaluation of peri-vaginal lymph nodes showed some similar aspects to those described for Brucella spp. detected animals by Ahmed et al. (2010) and Xavier et al. (2010) in studies with bovine mammary lymph nodes, and also though studies of Souza et al. (2015a) in buffalo uterine lymph nodes, where they described mild lymphoid hyperplasia with neutrophil moderate infiltration, and presence eosinophils in the paracortical and medullary sinuses with frequent plasmocytes. Different of the observations from Beytut et al. (2009) and Campos et al. (2009) that reported follicular hyperplasia, neutrophils, 
haemorrhage, oedema, macrophage enlargement and presence of epithelioid cells, giant Langhans cells, coagulative and caseous necrosis areas, and fibroplasia (typical granuloma), and all these descriptions did not observe in the present study.

Other described histological aspect in the present study was the presence of a lower lymphocyte density as also reported in cows (Dey et al., 2013) and buffaloes (Sousa et al., 2015b) positives for B. abortus. However, in this present study occurred a case where a lymph node presented lager lymphocyte density in the follicles and medullary cords (lymphoid hyperplasia), being accompanied by an increase in macrophage number in the medullary sinuses.

Immunohistochemical results found in the present study differed from that observed by Ahmed et al. (2012) referring to the presence of the associated bacterias with granulomatous lesion and macrophage cytoplasm positive immunostaining agents, where granulomatous reactions did not occur. Mense et al. (2004) affirms that the immunostaining may not manifest when the number of microorganisms is below the limit of detection IHC, and that results of non-immunostaining may be justified perhaps by the greater chronicity of the lesion and predominance of lymphocytes and plasmocytes, and lower macrophages.

In pregnant cows with brucellosis were found immunostaining in the cytoplasm of chorioallantoic trophoblastic cells, fewer macrophages and neutrophils that were freely around exudate and interstice, including uterine epithelial cell (Xavier et al., 2010). In present study was possible observe lower macrophages in endometrium with immunostaining.

Only three cases of non-gravid uterine tissue were immunoreactive in mild degree for Brucella antigens in endometrial interstitial macrophages. However, Pérez et al. (1998) evaluated bovine fetal tissues with specific anti-B abortus immunolabeling, and observed a positive reaction, mainly in the cytoplasm of macrophages, also in neutrophils and some cellular debris. In addition, a more intense antigenic reaction was observed mainly in cells of inflammatory function.

Changes in uterine tissue were predominantly mild, and were also absent from brucella agent immunostaining. In addition, no changes were observed in the endometrial glands. Possibly, some more intense changes (+++) would be more easily detected at a later stage of gestation. However, Jang et al. (2010) observed immunostaining of brucella in the uterine glands of bovine cows at the end of gestation. Negative immunostaining in samples that have isolated brucella may be associated with the low concentration of the microorganism in referenced samples. Therefore, a minimum colony-forming unit concentration would be required in the tissue for the chromogen to evidence the pathogen (Meador \& Deyoe, 1989a; Meador et al., 1989b).

The high positivity in the peri-vaginal lymph nodes was also observed by Xavier et al. (2010) that justified that the bacterium can be isolated from lymphoid organs of infected animals. However, bacteria were also detected in mammary nodules in $27 \%$ of cows that had a history of abortion as a consequence of B. abortus (Beytut et al., 2009). The high frequency of immunolabelled lymph nodes is due to the use of a monoclonal antibody, which is more sensitive (Wang et al., 2015).

\section{Conclusion}

Uterine tissue and peri-vaginal lymph nodes of non-pregnant and pregnant buffalo cows, until close to the 4th month, were serum reagents for Brucella spp. but did not have macroscopic changes in the uterine tissue and, in the peri-vaginal lymph nodes were less frequent. Microscopic lesions in the uterine tissue may occur with lymphocyte clustering in caruncle in the placentome, necrosis and desquamation of chorionic cells, and in the peri-vaginal lymph nodes may occur oedema, increased neutrophil frequency, lymphocyte depletion, lymphoid hyperplasia, congestion, haemorrhage, and vasculitis. The immunohistochemical reaction presented greater sensitivity, allowing the identification of the presence of the bacterial antigen in both tissues evaluated in this species. We emphasize the importance of the present study, justifying that the histological and immunohistochemical methods enable the diagnosis of brucellosis in females without disease suggestive signs, and that in reference it can direct future research in different animal species. 


\section{References}

Ahmed, Y. F., Sokkar, S. M., Ghazi, Y. A., Amin, A. S., \& Masboly, A. A. (2010). Pathological and molecular studies on mammary glands and supramammary lymph node of naturally brucella infected buffalo-cows. J Reprod Infertil, 1 (2), 33-40.

Ahmed, Y. F., Sokkar, S. M., Desouky, M., \& Madbouly, A. A. (2012). Pathological studies on buffalo-cows naturally infected with Brucella melitensis. Glob Vet, 9 (6), 663-668. 10.5829/idosi.gv.2012.9.6.66168

Baldi, P. C., \& Giambartolomei, G. H. (2013). Pathogenesis and pathobiology of zoonotic brucellosis in humans. Rev Sci Tech, 32 (1), 117-125. $10.20506 /$ rst.32.1.2192

Beytut, E., Şahin, M., Erginsoy, S., \& Sözmen, M. (2009). Pathological, immunohistochemical, and bacteriological findings in the mammary glands and supramammary lymph nodes of cows with a history of abortion due to Brucella abortus. Turkish J Vet Anim Sci, 33 (1), 37-43. 10.3906/vet-0705-12

Campos, D. I., Coelho, H. E., Kamimura, R., \& Arantes, V. M. (2009). Alterações microscópicas em linfonodos de bovinos sorologicamente positivos para brucelose. Arq Ciênc Vet Zool, 12 (2), 123-127. 10.25110/arqvet.v12i2.2009.2965

Corbel, M. J. (2006). Brucellosis in humans and animals. In: Food and Agriculture Organization of the United Nations, World Health Organization \& World Organization for Animal Health. Geneva.

Dey, S. K., Rahman, M. S., Rima, U. K., Hossain, M. Z., Chowdhury, G. A., Pervin, M., Habib, M. A. \& Khan, M. A. H. N. A. (2013). Serological and pathological investigation of brucellosis in dairy cows of Mymensingh district, Bangladesh. Bangl J Vet Med, 11 (2), 107-112. 10.3329/bjvm.v11i2.19124

Jang, J. S., Do, S. H., Ki, M. R., Hong, I. H., Park, J. K., Cho, Y. J., Park, S. J., Kim, T. H., Kwak, D. M., \& Jeong, K. S. (2010). Characterization of bovine Brucellosis in Korean native cattle by means of immunohistochemistry and proteomics. J Life Sci, 20 (2), 153-160. 10.5352/JLS.2010.20.2.153

Le Flèche, P., Jacques, I., Grayon, M., Dahouk, S. A., Bouchon, P., Denoeud, F., Nöckler, K., Neubauer, H., Guilloteau, L. A., \& Vergnaud, G. (2006). Evaluation and selection of tandem repeat loci for a Brucella MLVA typing assay. BMC Microbiol, 6 (9). 10.1186/1471-2180-6-9

Meador, V. P., \& Deyoe, B. L. (1989a). Intracellular localization of Brucella abortus in bovine placenta. Vet Pathol, 26 (6), 513-515, $10.1177 / 030098588902600609$

Meador, V. P., Deyoe, B. L., \& Cheville, N. F. (1989b). Pathogenesis of Brucella abortus infection of the mammary gland and supramammary lymph node of the goat. Vet Pathol, 26 (5), 357-368. 10.1177/030098588902600501

Meirelles-Bartoli, R. B., \& Mathias, L. A. (2009). Uso da reação de fixação de complemento na confirmação de resultados positivos do teste do antígeno acidificado tamponado para o diagnóstico sorológico da brucelose bovina. Ars Veter, 25 (2), 68-71. 10.15361/2175-0106.2009v25n2p068-071

Meirelles-Bartoli, R. B., Cruz, C. A., Moraes, R. S., Oliveira, R. A., Paula, E. M. N., Sousa, D. B., Assis, N. A., \& Mathias, L. A. (2020). Comparison of four serological tests for the diagnosis of swine brucellosis. Research, Society and Development, 9(7): 1-13, e493974418.

Mense, M. G., Borschel, R. H., Wilhelmsen, C. L., Pitt, M. L., \& Hoover, D. L. (2004). Pathologic changes associated with brucellosis experimentally induced by aerosol exposure in rhesus macaques (Macaca mulatta). Am J Vet Res, 65 (5), 644-652. 10.2460/ajvr.2004.65.644

Orlando, D. R., Costa, R. C., Abreu, R. V. S., Abreu, C. C., Nakagaki, K. Y. R., Wouters, A. T. B., Raymundo, D. L., \& Varaschin, M. S. (2014). Caracterização morfológica e imuno-histoquímica de lesões em casos de aborto bovino bacteriano e viral no sul de Minas Gerais. Pesq Vet Bras, 34 (10), 974-980. 10.1590/S0100-736X2014001000009.

Paulin, L. M. S., \& Ferreira Neto, J. S. (2008). Brucelose em búfalos. Arq Inst Biol, 75 (3), 389-401.

Pereira, A.S., Shitsuka, D.M., Parreira, F.J., Shitsuka, R. (2018). Metodologia da pesquisa científica. [e-book]. Santa Maria. Ed. UAB/NTE/UFSM. https://repositorio.ufsm.br/bitstream/handle/1/15824/Lic_Computacao_Metodologia-Pesquisa-Cientifica.pdf?sequence=1.

Pérez, J., Quezada, M., López, J., Casquet, O., Sierra, M. A., \& Martín de las Mulas, J. (1998). Immunohistochemical detection of Brucella abortus antigens in tissues from aborted bovine fetuses using a commercially available polyclonal antibody. J Vet Diagn Invest, 10 (1), 17-21. 10.1177/104063879801000104

Pranav, P., Sugat, S., \& Satadal, D. (2013). Histological changes in mammalian uterus in brucellosis. Asian J Biom Pharm Sci, 3 (22), 58-61.

Sousa, M. G. S., Salvarani, F. M., Bomjardim, H. A., Fonseca Jr, A. A., Preis, I. S., Brito, M. F., Leite, R. C., \& Barbosa, J. D. (2015ª). Infecção transplacentária e intrauterina por Brucella abortus em búfalos (Bubalus bubalis). Pesqui Vet Bras, 35 (11), 882-888. 10.1590/S0100-736X2015001100002

Sousa, M. G. S., Brito, M. F., Ubiali, D. G., Fonseca Jr, A. A., Silva, J. B., Belo Reis, A. S., Oliveira, Carlos, M. C., \& Barbosa, J. D. (2015b). Detecção de Brucella abortus em linfonodos de búfalas (Bubalus bubalis) em diferentes fases da gestação. Pesqui Vet Bras, 35 (12), 951-955. 10.1590/S0100736 X2015001200003

Sozmen, M., Erginsoy, S. D., Genc, O., Beytut, E., \& Özcan, K. (2004). Immunohistochemical and microbiological detection of Brucella abortus antigens in aborted bovine fetuses. Acta Vet Brno, 73, 465-472. 10.2754/avb200473040465

Wang, X., Wang, Y., Ma, L., Zhang, R., De, Y., Yang, X., Wang, C., \& Wu, Q. (2015). Development of an improved competitive ELISA based on a monoclonal antibody against lipopolysaccharide for the detection of bovine brucellosis. BMC Vet Res, 11, 118. 10.1186/s12917-015-0436-3

Xavier, M. N., Paixão, T. A., Poester, F. P., Lage, A. P., \& Santos, R. L. (2009). Pathological, immunohistochemical and bacteriological study of tissues and milk of cows and fetuses experimentally infected with Brucella abortus. J Comp Pathol, 140 (2-3), 149-157. 10.1016/j.jcpa.2008.10.004

Xavier, M. N., Paixão, T. A., Hartigh, A. B., Tsolis, R. M., \& Santos, R. L. (2010). Pathogenesis of Brucella spp. The Open Vet Sci J, 4, 109-118. 10.2174/1874318801004010109 